\title{
EVALUASI PENGELOLAAN PERIKANAN TUNA BERDASARKAN PENDEKATAN EKOSISTEM DI KABUPATEN PULAU MOROTAI
}

\author{
Rommy M. Abdullah ${ }^{1}$, Imran Taeran², Nebuchadnezzar Akbar ${ }^{2}$ \\ ${ }^{1}$ Program Studi IImu Kelautan, FPIK, Universitas Khairun, \\ Ternate, Indonesia \\ ${ }^{2}$ Program Studi Pemanfaatan Sumberdaya Perikanan, FPIK, \\ Universitas Khairun, Ternate, Indonesia \\ E-mail : nezzarnebuchad@yahoo.co.id
}

Received March 2020, Accepted August 2020

\begin{abstract}
ABSTRAK
Penelitian ini bertujuan untuk menentukan tingkat keberlanjutan setiap domain atau aspek dalam EAFM dan menentukan tingkat keberlanjutan kegiatan perikanan tuna di Kabupaten Pulau Morotai. Metode pengambilan data dilakukan dengan metode survei dengan cara wawancara/kuesioner dan FGD (Focus Group Discussion). Penentuan jumlah sampel menggunakan purposive sampling. Dengan analisis pendekatan EAFM, nilai komposit rata-rata seluruh domain berkisar antara 60-80 yang mencerminkan status dan kinerja sumber daya perikanan tuna yellowfin di Kabupaten Pulau Morotai yang baik dalam tingkat keberlanjutannya dengan menerapkan prinsip-prinsip EAFM. Namun, masih ada sejumlah indikator di setiap domain yang memiliki skor rendah sehingga diperlukan upaya untuk meningkatkan manajemen.
\end{abstract}

Kata Kunci : EAFM, Indikator, Pulau Morotai

\section{ABSTRACT}

EVALUATION OF TUNA FISHERIES MANAGEMENT BASED ON ECOSYSTEM APPROACH IN MOROTAI ISLAND DISTRICTS. This study aims to determine the level of sustainability of each domain or aspect in the EAFM and determine the level of sustainability of tuna fishery activities in the Morotai Island Districts. Methods of data taking was carried out with survey method by means of interview/questionnaires and FGD (Focus Group Discussion). Determination of samples quantity used purposive sampling. By the EAFM approach analysis, the average composite value of the entire domain was range of 60-80 which reflects the status and performance of yellowfin tuna fisheries resources in Morotai Island Districts was good in its level of sustainability by applying EAFM principles. However, there were still a number of indicators in each domain that had a low score so efforts are needed to improve management.

Keywords : EAFM, Indicator, Morotai Island 


\section{PENDAHULUAN}

Perikanan yellowfin tuna atau madidihang (Thunnus albacares) merupakan suatu aktivitas pengelolaan dan pemanfaatan sumberdaya ikan yang terus diupayakan dan ditingkatkan. Nilai ekonomis yang dimiliki ikan tuna menjadikannya sebagai salah satu komoditi utama dari subsektor perikanan nasional baik untuk konsumsi maupun komoditi ekspor. Di Provinsi Maluku Utara, Kabupaten Pulau Morotai merupakan salah satu daerah penghasil tuna terbesar atau meyumbang sekitar 34\% dari produksi tuna di Provinsi Maluku Utara (DKP-MU, 2018). Hal ini cukup beralasan karena daerah yang terletak di sebelah utara Provinsi Maluku Utara ini berbatasan langsung dengan Samudera Pasifik sehingga menjadikan perairannya sebagai kawasan perikanan paling produktif di Indonesia. Namun demikian, dengan semakin meningkatnya permintaan pasar terhadap ikan tuna maka tekanan terhadap penangkapan ikan tuna akan semakin meningkat. Tingginya tekanan terhadap perikanan tuna dikhawatirkan akan mengganggu sumberdaya ikan tuna itu sendiri. Jenis ikan tuna yang pada umumnya tertangkap di Perairan Maluku Utara masih tergolong muda (Abdullah et al, 2011). Hal ini dikhawatirkan berdampak pada kelestarian sumberdaya ikan tuna, dengan demikian diperlukan suatu pengelolaan perikanan tuna untuk menjamin keberlanjutan perikanan tuna. Pengelolaan yang dilakukan selama ini masih bersifat parsial dengan cenderung lebih besar untuk kepentingan sosial ekonomi masyarakat, dibandingkan kepentingan sumberdaya perikanan dan ekosistemnya dan kepentingan kebijakan perikanan.

Pendekatan yang dilakukan masih parsial dan belum terintegrasi dalam sebuah batasan ekosistem yang menjadi wadah dari sumberdaya ikan sebagai target pengelolaan. Oleh karenanya pendekatan terintegrasi melalui pendekatan ekosistem terhadap pengelolaan perikanan menjadi sangat penting. Salah satu metode pendekatan pengelolaan perikanan adalah dengan menggunakan pendekatan EAFM (Ecosystem Approach to Fisheries Management). Penilaian terhadap indikator-indikator yang terdapat pada EAFM diharapkan dapat menjadi mekanisme penilaian pengelolaan perikanan pada suatu wilayah. Adapun indikator yang menjadi dasar penilaian keberlanjutan terhadap suatu pengelolaan perikanan meliputi 6 aspek yakni sumberdaya ikan, habitat dan ekosistem perairan, teknik penangkapan ikan, sosial, ekonomi, dan kelembagaan.

Penelitian ini bertujuan menentukan tingkat keberlanjutan dari masing-masing domain atau aspek yang ada di dalam dan menentukan tingkat keberlanjutan kegiatan perikanan tuna di daerah Kabupaten Pulau Morotai. Analisis yang digunakan yaitu menggunakan pendekatan EAFM.

\section{MATERI DAN METODE}

\section{Tempat dan Waktu Penelitian}

Penelitian dilaksanakan di Kabupaten Pulau Morotai pada bulan Agustus - September 2018. 


\section{Metode Pengumpulan Data}

Metode pengambilan data dilakukan dengan teknik survey dengan metode penggalian data melalui wawancara/kuesioner. Selain itu dilakukan juga analisis data sekunder atau analisis dokumen terkait. Penentuan jumlah sampel ditentukan dengan teknik purposive sampling. Data diambil dari pengelolaan yellowfin tuna pada wilayah kajian penilaian indikator EAFM yaitu Kabupaten Pulau Morotai (termasuk ke dalam WPPNRI 715). Adapun data yang dianalisis adalah (1) habitat dan ekosistem, (2) sumberdaya ikan, (3) teknik penangkapan ikan, (4) sosial ekonomi, dan (5) kelembagaan. Data primer diambil dari hasil wawancara dan pengisian kuisioner dari nelayan dan tokoh masyarakat dan FGD (Focus Group Discussion). Data sekunder diperoleh dari DKP Provinsi Maluku Utara, DKP Kabupaten Pulau Morotai, P2O-LIPI (2006) yang diacu dalam Direktorat Tata Ruang Laut, Pesisir dan Pulau-Pulau Kecil (2010), Kementerian Kelautan Perikanan Republik Indonesia (2016), Kepmen KP No. 50 tahun 2017, dan WCPFC (Western and Central Pacific Fisheries Commition.

\section{Metode Analisis Data}

Analisis data dilakukan dengan memakai pendekatan multi-criteria analysis (MCA) yang mana sebuah set kriteria dibangun sebagai basis bagi analisis keragaan wilayah pengelolaan perikanan dilihat dari pendekatan ekosistem dalam pengelolaan perikanan melalui pengembangan indeks komposit. Teknik evaluasi ini pertama kali diaplikasikan di Indonesia oleh Direktorat Sumberdaya Ikan-Ditjen Perikanan Tangkap, Kementerian Kelautan dan Perikanan (2011) untuk kasus implementasi pendekatan ekosistem dalam pengelolaan perikanan di 11 WPP. Selanjutnya, pengembangan dan uji coba model teknik ini dilakukan oleh Jaya dan Nimi (2015), untuk evaluasi pengelolaan perikanan di WPP 711, 712, dan 573. Selain itu, kajian lain yang menggunakan teknik evaluasi pengelolaan berbasis ekosistem ini antara lain dilakukan pada perikanan tuna di perairan Sendangbiru Kabupaten Malang (Jaya et.al, 2017); pada perikanan Lobster Dengan Pendekatan EAFM Di Teluk Pelabuhanratu (Rombe et al., 2018); pada pengelolaan kawasan berbasis ekosistem di Kabupaten Raja Ampat dan Kabupaten Kepulauan Aru (Mulyana, 2018); pada Komoditas Udang di Kabupaten Sorong Selatan Provinsi Papua Barat (Diah et al., 2018). Adapun tahapannya sebagai berikut (Budiarto 2015):

1. Menentukan kriteria untuk setiap indikator dari masing-masing domain/aspek yang terdapat di dalam EAFM (aspek habitat dan ekosistem perairan, teknik penangkapan ikan, sumberdaya ikan, sosial, ekonomi dan kelembagaan).

2. Menentukan batasan nilai (reference point) untuk masing-masing kreteria pada setiap indikator

3. Menentukan bobot untuk setiap indikator. Pembobotan ditetapkan dalam skala 0-100. Indikator yang memiliki bobot besar dianggap 
memiliki nilai kepentingan paling tinggi dalam domain tersebut. Pembobotan maksimal tiap domain/aspek adalah 100 yang dibagi habis dalam setiap indikator

4. Mengkaji keragaan masing-masing indikator yang diuji

5. Menentukan nilai skor untuk setiap indikator dengan menggunakan skor Likert (berbasis ordinal 1, 2, 3) sesuai dengan keragaan masingmasing indikator. Nilai 1 merupakan skor terendah yang menandakan keadaan yang jelek (merah), dan nilai 3 merupakan skor tertinggi yang menandakan keadaan yang bagus (hijau) (Tabel 1). Dari proses pemberian skor tersebut kita bisa mengetahui indikator-indikator mana yang berada dalam kondisi bagus ataupun jelek.

Tabel 1. Nilai skor Indikator

\begin{tabular}{cc}
\hline Skor Indikator & Deskripsi \\
\hline 1 & Jelek/Buruk \\
2 & Sedang \\
3 & Bagus \\
\hline
\end{tabular}

6. Menentukan nilai dari masing-masing indikator dengan formula:

Nilai Indikator $=$ Bobot $x$ Nilai Skor

7. Menentukan nilai dari masing-masing aspek/domain dengan cara mengakumulasikan nilai indikator yang didapat didalam setiap aspek.

8. Nilai dari masing-masing domain/aspek kemudian dianalisis dengan meng-gunakan analisis komposit sederhana berbasis rataan aritmatik yang kemudian ditampilkan dalam bentuk model bendera. Indeks komposit ini merupakan nilai konversi nilai total setiap aspek/domain EAFM. Proses konversi ini dilakukan untuk memperoleh batasan yang baku dari nilai EAFM. Nilai total dari perkalian komponen EAFM selanjutnya di konversi dalam skala 0-100. Konversi ini diperlukan untuk memudahkan pengkatagorian suatu domain EAFM. Nilai skala setiap domain/aspek yaitu:

$$
N K-i=\frac{\frac{C_{a t-i}}{C_{a t-i \max }} \times 100}{N}
$$

Dimana:

$\mathrm{C}_{\text {at-i }} \quad=$ niai total yang didapat dalam sutu aspek/domain

$\mathrm{C}_{\text {at-imax }}=$ nilai maksimal dalam suatu aspek/domain yang diperoleh saat semua indikator memiliki skor 3.

9. Menentukan nilai komposit total dari seluruh domain/aspek EAFM yang dikaji. Nilai komposit ditentukan dari nilai rata-rata dari seluruh domain yang dikaji dalam wilayah EAFM. Hasil ini kemudian dikonversi menjadi nilai dengan skala 0-100. Nilai 100 termasuk paling tinggi dan paling baik kondisinya, dan nilai yang rendah tergolong paling buruk kondisinya. Nilai yang didapat kemudian dideskripsikan atas 5 kelompok atau kategori. Kelima kategori ini menggambarkan 5 tingkatan status pengelolaan perikanan suatu wilayah (Tabel 2). 
Tabel 2. Batasan skor nilai domain dan agregat

\begin{tabular}{|c|c|c|c|}
\hline \multicolumn{2}{|c|}{ Rentang Nilai } & \multirow{2}{*}{$\begin{array}{l}\text { Model } \\
\text { Bendera }\end{array}$} & \multirow{2}{*}{ Deskripsi } \\
\hline Rendah & Tinggi & & \\
\hline 1 & 20 & Merah & $\begin{array}{l}\text { Buruk dalam menerapkan } \\
\text { EAFM }\end{array}$ \\
\hline 21 & 40 & $\begin{array}{l}\text { Kuning } \\
\text { muda }\end{array}$ & $\begin{array}{l}\text { Kurang dalam menerapkan } \\
\text { EAFM }\end{array}$ \\
\hline 41 & 60 & Kuning & $\begin{array}{l}\text { Sedang dalam menerapkan } \\
\text { EAFM }\end{array}$ \\
\hline 61 & 80 & Hijau Muda & Baik dalam menerapkan EAFM \\
\hline 80 & 100 & Hijau Tua & $\begin{array}{l}\text { Baik Sekali dalam menerapkan } \\
\text { EAFM }\end{array}$ \\
\hline
\end{tabular}

\section{HASIL DAN PEMBAHASAN}

\section{Evaluasi Masing-Masing Indikator pada Setiap Domain}

Penilaian setiap atribut (indikator) dari parameter EAFM Yellowfin tuna Kabupaten Morotai adalah rataan nilai dari keseluruhan paramater yang dikaji. Skor atribut sebagaimana yang telah disampaikan dalam metode berkisar 1-3. Dalam konteks atribut EAFM Yellowfin tuna Kabupaten Morotai, skor indikator yang diberikan adalah rataan nilai skor Yellowfin tuna Kabupaten Morotai (Tabel 3).

Tabel 3. Skor rata-rata atribut pad setiap domain

\begin{tabular}{lcc}
\hline Domain & Skor Indikator & Deskripsi \\
\hline Sumberdaya Ikan & 2,33 & Sedang \\
Habitat dan Ekosistem & 2,77 & Tinggi \\
Teknik Penangkapan Ikan & 2,50 & Tinggi \\
Ekonomi & 2,00 & Sedang \\
Sosial & 1,33 & Rendah \\
Kelembagaan & 2,10 & Sedang \\
\hline
\end{tabular}

Hasil skoring dari setiap atribut yang dikaji dari domain EAFM pada perikanan Yellowfin tuna di Kabupaten Pulau Morotai berkisar 1,33-2,77. Rata-rata skor indikator berada pada status rendah-tinggi. Domain yang memiliki skor atribut yang tergolong rendah yaitu domain Sosial. Rendahnya nilai skor atribut pada domain sosial utamanya disebabkan masih tingginya frekuensi konflik antar nelayan terjadi antara nelayan tuna dengan alat tangkap handline dan alat tangkap purse seine dalam hal perebutan daerah penangkapan ikan (rumpon), dimana nelayan purse seine terkadang menangkap di daerah sekitar rumpon milik nelayan handline.

Domain yang memiliki rata-rata skor rendah lainnya adalah domain ekonomi dan kelembagaan. Namun rendahnya skor domain tersebut masih berada pada reference point. Artinya kontribusi ekonomi dan 
kelembagaan tergolong relatif rendah namun masih dalam batas koridor normal yang berarti peranan dan kontribusinya masih dapat ditolerir. Rendahnya skor domain ekonomi utamanya disebabkan karena sebagian besar nelayan tuna di Kabupaten Morotai tidak memiliki tabungan, sementara rendahnya skor domain kelembagan utamanya disebabkan karena masih ditemukannya pelanggaran terhadap aturan-aturan perikanan seperti cara penangkapan tidak ramah lingkungan yaitu menggunakan dan bom untuk menangkap ikan serta penggunaan pupuk urea dan solar untuk merusak terumbu karang.

\section{Evaluasi Nilai Komposit pada Setiap Domain}

Hasil evaluasi terhadap nilai komposit pada setiap domain EAFM pada perikanan yellowfin tuna di Kabupaten Pulau Morotai dari hasil perhitungan diperoleh pada kisaran antara 46,77 - 88,33. Hal ini mengindikasikan bahwa status pengelolaan perikanan yellowfin tuna di Kabupaten Pulau Morotai tergolong dalam kategori sedang-baik sekali (Gambar 1).

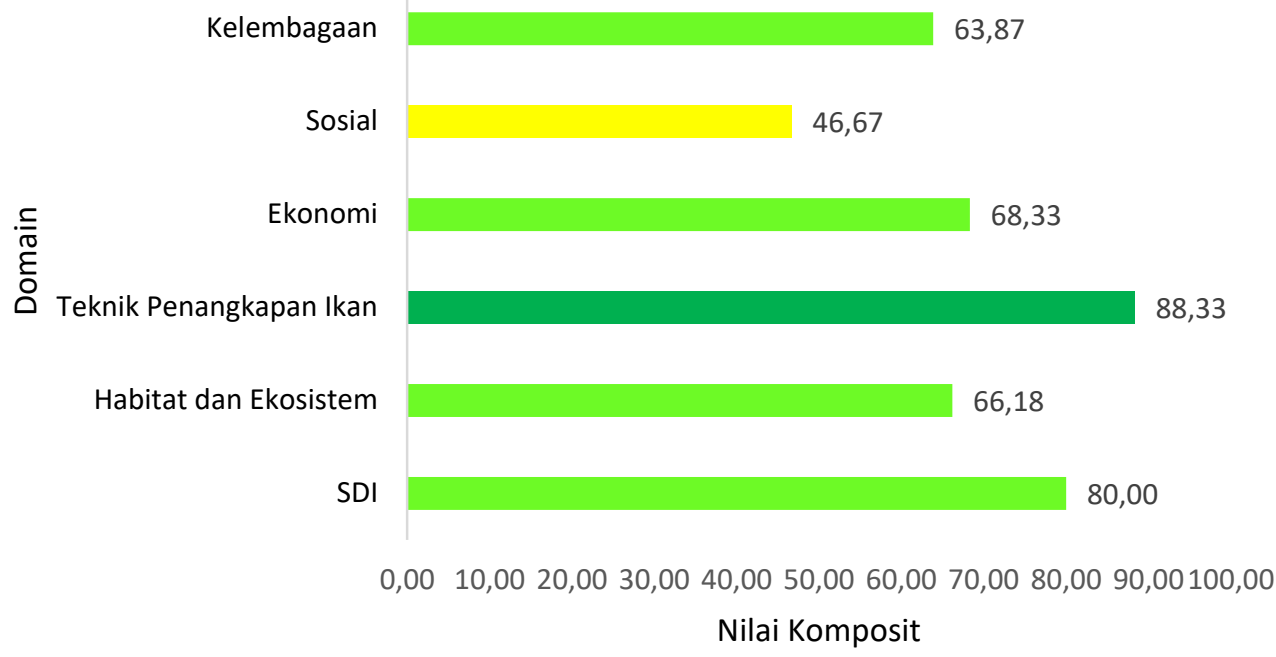

Gambar 1. Status dan Performa Pengelolaan Sumberdaya Perikanan Yellowfin tuna di Kabupaten Pulau Morotai

Domain teknik penangkapan ikan memiliki nilai komposit yang paling besar $(\mathrm{NK}=88,33)$ dengan deksripsi sangat baik dalam dalam tingkat keberlanjutannya dengan menerapkan prinsip-prinsip EAFM (Gambar 1). Sementara nilai komposit yang paling rendah adalah domain sosial $(46,67)$ dengan deksripsi sedang dalam dalam tingkat keberlanjutannya dengan menerapkan prinsip-prinsip EAFM. Adapun domain sumberdaya ikan, habitat dan ekosistem, ekonomi, dan kelembagaan memiliki nilai komposit tergolong baik $(\mathrm{NK}=61-80)$. Nilai komposit rata-rata dari keseluruhan domain diperoleh sebesar 71 yang mencerminkan status dan 
performa sumberdaya perikanan yellowfin tuna di Kabupaten Pulau Morotai adalah baik dalam tingkat keberlanjutannya dengan menerapkan prinsip-prinsip EAFM, walaupun masih terdapat beberapa indikator yang memiliki skor rendah. Status tersebut merupakan cerminan dari kinerja indikator-indikator yang yang terdapat pada kelima domain yang dievaluasi.

Indikator-indikator tersebut adalah proporsi ikan juvenile yang ditangkap, tren ukuran ikan, dan "range collapse" (domain SDI); status ekosistem terumbu karang, habitat khusus/unik, dan Perubahan iklim terhadap kondisi perairan dan habitat (domain Habitat dan Ekosistem); sertifikasi awak kapal perikanan sesuai dengan peraturan dan modifikasi alat penangkapan ikan dan alat bantu penangkapan (domain teknik penangkapan ikan); kepemilikan asset dan rasio tabungan (domain ekonomi); partisipasi pemangku kepentingan, konflik perikanan, dan pemanfaatan pengetahuan lokal dalam pengelolaan sumberdaya ikan (domain sosial); dan kepatuhan terhadap prinsip-prinsip perikanan yang bertanggung jawab dalam pengelolaan perikanan yang telah ditetapkan baik secara formal maupun non-formal, mekanisme pengambilan keputusan, dan Rencana Pengelolaan Perikanan (domain kelembagaan).

Indikator-indikator inilah yang menurut analisis EAFM merupakan permasalahan yang menyebabkan pengelolaan perikanan yellowfin tuna berbasis ekosistem di Kabupaten Pulau Morotai teridentifikasi masih belum optimal dalam menerapkan prinsip-prinsip EAFM. Pengelolaan perikanan yellowfin tuna berbasis ekosistem bertujuan untuk melindungi struktur, keanekaragaman dan fungsi ekosistem melalui seperangkat aksi pengelolaan yang menitikberatkan pada komponen biofisik dari ekosistem dan untuk memenuhi tujuan mencapai tujuan sosial dan kebutuhan manusia dalam hal pangan dan manfaat ekonomi melalui tindakan pengelolaan yang menitikberatkan pada aktivitas penangkapan dan target sumberdaya. Untuk itu, diperlukan suatu rekomendasi perbaikan yang dapat digunakan sebagai acuan dalam memperbaiki pengelolaan perikanan yellowfin tuna di Kabupaten Pulau Morotai yang ada, sebagaimana tercermin pada indikator-indikator yang teridentifikasi memiliki nilai indeks atau kinerja rendah.

Melalui pendekatan wawancara menggunakan metode benchmarking terhadap tokoh kunci (keyperson) dalam pengelolaan perikanan di Kabupaten Pulau Morotai dan Provinsi Maluku Utara, dan dengan berpedoman pada arahan rekomendasi yang tertuang dalam hasil kerja dari stakeholder's perikanan Indonesia yang tergabung dalam dari National Working Group on Ecosystem Approach to Fisheries management, Direktorat Sumber Daya Ikan, Kementerian Kelautan dan Perikanan Republik Indonesia (2014) dibutuhkan beberapa rekomendasi strategi atau langkah alternatif perbaikan yang menjadi prioritas pengelolaan perikanan yellowfin tuna di Kabupaten Pulau Morotai menurut masing-masing domain dan indikator yang diarahkan untuk peningkatan kesejahteraaan nelayan kecil dengan tetap memperhatikan pemanfaatan sumberdaya ikan secara optimal dan berkelanjutan. 


\section{KESIMPULAN}

Analisis indeks dekomposit EAFM, domain teknik penangkapan ikan di Kabupaten Pulau Morotai memiliki nilai komposit yang paling tinggi dan mendeskripsikan status sangat baik dalam tingkat keberlanjutannya dengan menerapkan prinsip-prinsip EAFM. Sementara domain sosial memiliki nilai komposit yang paling rendah dengan deksripsi sedang dalam tingkat keberlanjutannya dengan menerapkan prinsip-prinsip EAFM. Adapun domain sumberdaya ikan, habitat dan ekosistem, ekonomi, dan kelembagaan memiliki nilai komposit tergolong baik dalam tingkat keberlanjutannya dengan menerapkan prinsip-prinsip EAFM. Nilai komposit rata-rata dari keseluruhan domain diperoleh sebesar 71 (NK=6180) yang mencerminkan status dan performa sumberdaya perikanan yellowfin tuna di Kabupaten Pulau Morotai adalah baik dalam tingkat keberlanjutannya dengan menerapkan prinsip-prinsip EAFM. Namun demikian, masih terdapat beberapa indikator pada masing-masing domain domain yang memiliki skor rendah sehingga diperlukan upaya-upaya perbaikan dalam pengelolaan.

\section{DAFTAR PUSTAKA}

Abdullah RM, Sugeng HW, Daniel RM, Fedi A.M. Sondita. 2011. Keberlanjutan perikanan tangkap di Kota Ternate pada Dimensi Ekologi. Buletin PSP, 19 (1) : 113-126.

Budiarto A. 2015. Pengelolaan Perikanan Rajungan dengan Pendekatan Ekosistem di Perairan Laut Jawa (WPPNRI 712). Thesis. IPB. Bogor.

Diah AP, Abudarda R, Ahmad F, Irwanto. 2018. Status Pengelolaan Perikanan dengan Pendekatan Ekosistem (P3E) pada Domain Sumberdaya Ikan untuk Komoditas Udang di Kabupaten Sorong Selatan Provinsi Papua Barat. Jurnal Airaha, 7 (2) : 47-59.

Direktorat Tata Ruang Laut, Pesisir dan Pulau-Pulau Kecil, Kementerian Kelautan Perikanan Republik Indonesia. 2010. Bantuan Teknis Penyusunan Rencana Zonasi Rinci Kabupaten Pulau Morotai. Jakarta.

Direktorat Sumberdaya Ikan, Kementerian Kelautan Perikanan Republik Indonesia. 2011. Kajian Awal Keragaan Pendekatan Ekosistem Dalam Pengelolaan Perikanan (Ecosystem Approach to Fisheries Management) Di Wilayah Pengelolaan Perikanan Indonesia. Direktorat Sumberdaya Ikan - Direktorat Jenderal Perikanan Tangkap - Kementerian Kelautan dan Perikanan, WWF-Indonesia dan Pusat Kajian Sumberdaya Pesisir dan Lautan - Institut Pertanian Bogor. 
Direktorat Sumberdaya Ikan, Kementerian Kelautan Perikanan Republik Indonesia. 2014. Modul Penilaian indikator untuk Perikanan dengan Pendekatan Ekosistem. DIT. SDI KKP Jakarta FAO. 2003. Ecosystem Approach to Fisheries. FAO Technical Paper.

Dinas Kelautan Dan Perikanan Provinsi Maluku Utara, 2018. Statistik Perikanan Tangkap Provinsi Maluku Utara.

Jaya I, Zulbainarni N. 2015. Pengembangan dan Uji Coba Model Evaluasi Pengelolaan Perikanan melalui Pendekatan Ekosistem. Jurnal Kebijakan Perikanan Indonesia, 7 (2) : 115-131.

Jaya M. M, Wiryawan B, Simbolon D. 2017. Analisis Tingkat Pemanfaatan Sumberdaya Ikan Tuna Dengan Metode Spawning Potential Ratio Di Perairan Sendangbiru. Jurnal IImu dan Teknologi Kelautan Tropis, 9 (2) : 597-604.

Mulyana. 2018. Penilaian Indikator EAFM di Kabupaten Raja Ampat dan Kabupaten Kepulauan Aru. Jurnal Mina Sains 4 (1) : 1-11.

Rombe K.H, Wardiatno Y, Adrianto L. 2018. Pengelolaan Perikanan Lobster Dengan Pendekatan EAFM Di Teluk Palabuhanratu. Jurnal IImu dan Teknologi Kelautan Tropis, 10 (1) : 231-241. 